\title{
Product Market Competition, Corporate Governance, and Firm Value: Evidence from the EU-Area*
}

\author{
Manuel Ammann ${ }^{\mathrm{a}}$, David Oesch ${ }^{\mathrm{a}, \mathrm{b}}$, and Markus M. Schmid ${ }^{\mathrm{c}, \#}$ \\ ${ }^{\mathrm{a}}$ Swiss Institute of Banking and Finance, University of St. Gallen, CH-9000 St. Gallen, \\ Switzerland \\ ${ }^{\mathrm{b}}$ Department of Finance, Leonard N. Stern School of Business, New York University, \\ New York, NY 10012, USA \\ ${ }^{\mathrm{c}}$ University of Mannheim, Finance Area, D-68131 Mannheim, \\ Germany
}

This version: 27 February 2011

\begin{abstract}
This paper investigates whether the valuation effect of corporate governance depends on the degree of competition in the companies' product markets in a large international sample covering 14 countries from the European Union (EU). Besides providing external validity of previous U.S.-centered studies, the study uses more comprehensive and reliable measures of both product market competition and corporate governance. Consistent with the hypothesis that product market competition acts as a substitute for corporate governance as competitive pressure enforces discipline on managers to maximize firm value, our results show that corporate governance significantly increases firm value in non-competitive industries only. When investigating the channels through which firm value may be increased, we find that good governance for firms in noncompetitive industries leads them to have more capital expenditures, spend less on acquisitions and be less likely to diversify. Our results are robust to a large number of robustness checks including the use of alternative measures of competition and governance, as well as using alternative regressions specifications.
\end{abstract}

Keywords: Product market competition, Corporate governance, Firm valuation

JEL Classification: G34, G38, L1

\footnotetext{
* We are grateful to an anonymous referee, Christine Csibi, John Doukas (the editor), Sadok El Ghoul, Michel Habib, Daniel Hoechle, Markus Schimmer, Paul Söderlind and seminar participants at the University of St. Gallen, the University of Zurich, and the 2010 Financial Management Association European Conference in Hamburg, Germany for useful comments. Financial support by the Swiss National Science Foundation is gratefully acknowledged.

${ }^{\#}$ Corresponding author: Tel.: +49-621-181-37-54; E-mail: schmid@bwl.uni-mannheim.de.

Address: University of Mannheim, Finance Area, Chair for Business Administration and Corporate Governance, D-68131 Mannheim, Germany.
} 


\section{Introduction}

This paper investigates the relation between product market competition, corporate governance, and firm value in a large international sample covering 14 countries from the European Union (EU). Besides providing external validity of previous studies focusing on U.S. firms, this study uses more comprehensive and reliable measures of both product market competition and corporate governance.

A large body of literature documents that good corporate governance leads to higher firm valuations by mitigating the conflicts of interest between managers and shareholders (e.g., Yermack, 1996; Gompers et al., 2003 (“GIM”); Cremers and Nair, 2005; Core et al., 2006; Chhaochharia and Grinstein, 2007; Bebchuck et al., 2009). A number of recent studies, however, raise the question whether all firms benefit equally from good corporate governance. In fact, product market competition may act as a substitute for corporate governance as competitive pressure enforces discipline on managers to maximize firm value. Consequently, corporate governance may matter more in less competitive industries than in more competitive industries.

Some recent studies provide empirical support for this hypothesis. Giroud and Mueller (2011, "GM") find the strength of the relation between long-term stock returns, firm value, as well as operating performance and corporate governance to decrease monotonically in the degree of product market competition. In the most competitive industries there is no significant relation between corporate governance and the three alternative measures of company performance. In contrast, this relation is strong, positive, and significant in non-competitive industries. This finding is corroborated in Giroud and Mueller (2010) who show that firms in non-competitive industries experience a significant drop in operating performance after the passage of business combination laws while the operating performance of firms in competitive industries remains largely unaffected. By reducing the threat of hostile takeovers, busi- 
ness combination laws weaken corporate governance and increase the opportunity for managerial slack. Hence, competition in the product market seems to act as a substitute for a poor corporate governance and pressure managers towards a maximization of firm value independent of a deterioration in the firms' corporate governance. Chhaochharia et al. (2009) find supporting evidence by investigating the effect of the Sarbanes Oxley law on firm efficiency. They find that firms in less competitive industries experienced significantly larger increases in efficiency upon introduction of Sarbanes Oxley than firms in more competitive industries. They also find that firms in less competitive industries were more likely to be associated with financial restatements, insider trading, and backdating during that period than firms in more competitive industries. All these findings suggest that competition on a firm's product market is associated with a reduction of agency problems. Consistent with this finding, Cremers et al. (2008) show that firms in more competitive industries have more takeover defenses. They argue that competition is a substitute for the market of corporate control with more information available in competitive markets making monitoring less costly. Kadyrzhanova and Rhodes-Kropf (2011) take into account the heterogeneity among take-over provisions and distinguish between delay and non-delay provisions. They show that delay provisions (which allow managers to impose a delay on potential acquirers) have a significant bargaining effect and are positively related to firm value in concentrated industries. In contrast, non-delay provisions have a negative effect on firm value and significantly more so in concentrated industries. This latter finding is in line with the findings of Giroud and Mueller (2010, 2011), who do not distinguish between delay and non-delay provisions. ${ }^{1}$

All of the existing evidence is focused on the U.S., and evidence from other countries may provide important external validity of the U.S. evidence. Moreover, all studies concen-

\footnotetext{
${ }^{1}$ A related literature investigates the relationship between product market competition and managerial incentive schemes. Cuñat and Guadalupe (2005) and Baggs and De Bettignies (2007) both find that a higher level of product market competition increases the performance pay sensitivity of compensation schemes in U.K. and Canadian firms, respectively. Beiner et al. (2011) account for a possible non-linearity in this relationship and find that managerial incentive schemes are a convex function of product market competition in a sample of Swiss firms.
} 
trating on U.S. firms are plagued by similar problems in the measurement of corporate governance and competition. First, corporate governance is measured by GIM's index. This index mainly focuses on anti-takeover provisions, which represent only one dimension of corporate governance. Board characteristics (e.g., Yermack, 1996; Faleye, 2007), CEO ownership and power (e.g. Habib and Ljungqvist, 2005; Adams et al., 2005) and other aspects of corporate governance are neglected. Second, all these studies either measure competition using a Herfindahl-Hirschman index (HHI), which is based on all firms in the Compustat universe (e.g., Giroud and Mueller, 2010, 2011; Cremers et al., 2008; Kadyrzhanova and Rhodes-Kropf, 2011), a HHI from the U.S. Economic Census, which is calculated using the largest 50 companies within each industry, or the so-called "four-firm domestic concentration ratio" from the U.S. Economic Census, which is based on the largest four companies within each industry (e.g., Cremers et al., 2008). Ali et al. (2009), however, argue that competition measures calculated exclusively with Compustat data, and thereby only covering the public firms within an industry, are poor proxies for actual competition. In fact, the correlation between the Compustat-based competition measures and the HHI obtained from the U.S. Census, which is based on the 50 largest firms within an industry regardless of whether they are listed or unlisted, is only 13 percent. However, even this HHI from the U.S. Census is affected with a number of problems. First, it only covers manufacturing firms. Given the increasing importance of other industries for the U.S. economy (and developed countries' economies worldwide), we believe that it is important to include non-manufacturing industries in the analysis. Moreover, the HHIs from the U.S. Census are updated only once in five years. Product market competition, however, is likely to change faster than in five-year intervals, in particular for young and growing industries. ${ }^{2}$

\footnotetext{
${ }^{2}$ As the U.S. Census' two last updates took place in 2002 and 2007, competition would remain unchanged over the whole sample period in our study.
} 
In this study, we investigate the relation between product market competition, corporate governance, and firm value in a large international sample covering 14 EU countries. We thereby use more comprehensive and reliable measures of product market competition and corporate governance than used in previous U.S.-based research. ${ }^{3}$ We measure competition based on a HHI over all listed firms contained in Thomson Financial's Worldscope database and all non-listed firms contained in Bureau van Dijk's Amadeus database, which provides extensive coverage of non-listed firms throughout Europe. This HHI improves upon that from the U.S. Census in that it can be calculated for each year, covers all industries, and is not restricted to the 50 largest companies within each industry. Moreover, we combine the product markets of all $14 \mathrm{EU}$ countries to account for the fact that the markets in these countries are strongly interrelated and exports / imports to and from other EU countries make up a large part of the respective product markets.

Our measure of corporate governance is based on 64 different governance attributes obtained from Governance Metrics International (GMI). GMI classifies these 64 attributes into six categories, namely board accountability, financial disclosure and internal control, shareholder rights, remuneration, market for control, and corporate behavior. To condense the information contained in these 64 attributes, we follow prior literature and construct an additive corporate governance index (e.g., GIM; Aggarwal et al., 2009). Specifically, we first code a value of one to each governance attribute that a firm has in place and zero otherwise and then calculate the percentage of attributes a company has adopted (i.e., attributes which have been assigned a value of one). In a robustness check, we use an alternative version of this index that excludes attributes that are in place at more than 90 or less than 10 percent of the sample firms. We thereby attempt to account for the fact that certain governance attributes are adopted by a very large percentage of sample firms and other attributes by almost none. These cor-

\footnotetext{
${ }^{3}$ Even though our measures are more comprehensive than the ones used in earlier research, one important caveat remains. Our measures of governance and competition are endogenous so that, strictly speaking, our results cannot be interpreted in a casual sense.
} 
porate governance attributes naturally will have a very low variance and potentially weaken the effect of our corporate governance indices.

We use a number of alternative approaches to investigate whether the valuation effect of corporate governance depends on the competitiveness of its product markets. First, we follow GM and investigate whether the effect of corporate governance on firm value is different across the three terciles of the empirical distribution of HHI, our measure for product market competition. Consistent with GM, we find the effect of corporate governance to be significant only in the highest tercile of the HHI distribution. Hence, consistent with the hypothesis that product market competition acts as a substitute for corporate governance, corporate governance significantly increases firm value in non-competitive industries only. We check the robustness of this result by using the median, quartiles, or quintiles to classify our sample observations into more and less competitive firm-years. We also construct the HHIs based on the companies' total assets instead of sales, use the yearly distribution of the HHIs, instead of pooling all observations, to classify firm-years into competitive and non-competitive, and use only the listed companies covered by Worldscope to construct the HHIs, and find the results to remain qualitatively unchanged. We also use the approach of Kadyrzhanova and RhodesKropf (2011) and include an interaction term between corporate governance and competition in our Q-regressions or estimate regressions of Tobin's Q on the corporate governance index and control variables for sub-samples of firms in competitive and non-competitive industries. Again, our results indicate that corporate governance increases company value in noncompetitive industries only where the disciplining effect of the product market is presumably weak.

Besides contributing to the literature by providing evidence consistent with papers using U.S. data, we also provide new and original evidence on the mechanisms through which corporate governance affects firm value in concentrated industries. We find three main channels 
through which firm value is positively influenced by corporate governance in non-competitive industries. The first channel is an investment channel. We first show that corporate governance is positively related to capital expenditures. When differentiating between different levels of competition, the positive effect of governance on capital expenditures only prevails for companies that are operating in relatively less competitive industries whereas there is no effect for companies operating in the most competitive industries. Hence, corporate governance seems to act as a substitute for the absent pressure from competition on the product markets. The second channel we document is an acquisition channel. We show that well-governed companies operating in concentrated industries spend significantly less money on acquisitions than poorly-governed companies in concentrated industries. In contrast, governance is not significantly related to acquisition spending in competitive industries. Again, governance seems to substitute for the absence of competition on the product markets. The third and final channel we document is a diversification channel. We provide evidence that good corporate governance reduces the likelihood that firms operating in non-competitive industries engage in value-destroying diversification.

The remainder of the paper is organized as follows. Section 2 describes the data and construction of variables used in the study. Section 3 presents the results from the empirical analysis. Section 4 concludes.

\section{Data and variables}

In this section, we first describe the corporate governance data used in this study and how we condense this data into the governance index employed in the empirical analysis. We also describe our measure of product market competition and the financial variables used in the study. 


\subsection{Firm-level data on corporate governance attributes}

We use data on firm-level corporate governance attributes provided by Governance Metrics International (GMI), which started providing governance data in 2003. GMI constructs a governance rating for firms they cover using a proprietary scoring algorithm. To construct these ratings (which we do not use in this paper), GMI assembles information on individual governance attributes. We use these individual governance attributes for the construction of our own governance index. The starting point of our sample are all firm-year observations of companies which are located in the European Union (EU) in GMI's database over the time period from 2003 to 2007 . After merging this data with financial data from Thomson Financial's Worldscope database, our sample includes 3,102 firm-year observations with complete data. The 14 EU countries covered in our study are Austria, Belgium, Denmark, Finland, France, Germany, Greece, Ireland, Italy, Netherlands, Portugal, Spain, Sweden, and the UK.

We use a sample of 64 governance attributes that have been gathered by GMI. For each of these attributes, GMI assesses if a firm attains a minimum level of implementation and accordingly codes each attribute with a one if it is in place (indicating good corporate governance) and a zero otherwise. The 64 attributes we consider are sub-categorized by GMI into six categories, namely 1) board accountability, 2) financial disclosure and internal control, 3) shareholder rights, 4) remuneration, 5) market for control, and 6) corporate behavior. Table 1 provides an overview of the 64 governance attributes and shows the percentage of firms meeting these criteria according to GMI's thresholds. A comparison of Table 1 with corresponding results from studies using the Institutional Shareholder Services (ISS) database such as, for example, Aggarwal et al. (2009), shows that the level of implementation of governance attributes is similar for the governance attributes provided by both data providers. Using these 64 governance attributes, we construct our corporate governance index, denoted CGI, by simply calculating the percentage of attributes a company has adopted (i.e., attributes which have 
been assigned a value of one). If a company satisfies all 64 (32 out of the 64) attributes, CGI for this company would be equal to $100 \%(50 \%)$. If the GMI database only provides information on 50 out of the 64 attributes on a particular company and all 50 of them are in place, this company's CGI equals $100 \%$. The additive nature of index construction is a common feature in the literature (see, e.g., GIM; Drobetz et al., 2004; Bebchuck and Cohen, 2005; Aggarwal et al., 2009; Bebchuk et al., 2009).

\subsection{Measure of product market competition}

We use the Herfindahl-Hirschman index ("HHI") as a measure for product market competition. For each year, we calculate this index by summing up the squared market shares of all firms in a given industry and divide it by the square of the sum of all market shares. To compute the HHI, we use all firms that are listed in a country and for which sales data is available on Worldscope. In addition, we include non-listed firms by merging the Worldscope data with data from Bureau van Dijk's Amadeus database, which provides extensive coverage of non-listed firms across Europe. ${ }^{4}$ We exclude firm-years where sales are missing or negative. We classify industries according to the first two digits of a firm's four-digit SIC-code. In line with the close trade relationships that EU member countries have among each other, we treat the European Union as one product market (as opposed to treating each of the 14 countries in our sample as isolated and separate markets). We believe that this is the most reasonable way to define the relevant product market for our sample firms. Given that the firms included in the GMI database are the largest firms of each country, it is more reasonable to assume that they are active across the Europe Union instead of only in their country of origin. However, in a robustness check, we will use country-wide product markets as well.

\footnotetext{
${ }^{4}$ For our 14 sample countries the number of non-listed firms covered are 9,065 (Austria), 15,345 (Belgium), 8,208 (Denmark), 5,587 (Finland), 49,689 (France), 84,624 (Germany), 3,700 (Greece), 8,338 (Ireland), 49,093 (Italy), 31,354 (Netherlands), 7,321 (Portugal), 39,055 (Spain), 14,542 (Sweden), and 81,897 (United Kingdom).
} 


\subsection{Financial data}

We obtain the financial data for the companies included in our sample from Worldscope. We use Tobin's Q as a measure of firm value. We compute Tobin's Q as the sum of total assets less the book value of equity plus the market value of equity, divided by total assets (e.g., see Agrawal and Knoeber, 1996; Loderer and Peyer, 2002). In the empirical analysis in Section 3, we include several control variables. We control for firm size by using the logarithm of total assets. In accordance with similar studies for the U.S., we also control for firm age. Since Worldscope has only very sparse coverage of firm age, we construct a proxy for firm age by calculating the number of months since a company's stock started trading. In a robustness test, we additionally include the percentage of closely held shares, defined as the percentage of a company's shares owned by large blockholders with equity stakes in excess of 5\% of the company's equity, which we also obtain from Worldscope. In the analysis investigating potential channels through which firm value may be affected by corporate governance in non-competitive industries at the end of Section 3, we additionally use data on capital expenditures, acquisition spending, and the different product market segments in which a company is active. We obtain this data from Worldscope as well.

Table 2 provides summary statistics of the main variables we use in the paper, Tobin's Q, CGI, and HHI. All our results are based on the data as we obtained it from Worldscope. However, winsorizing the data, e.g., at the $1^{\text {st }}$ and $99^{\text {th }}$ level, does not change any of our results. In unreported tests, we also investigate the correlation between CGI and HHI. The correlation between HHI and CGI is 0.05 for the whole sample and remarkably stable over the years (0.04 or 0.05 in every year other than 2004) and with the exception of 2004, none of these correlations are significantly different from zero. In 2004, the correlation is borderline significant and has a value of 0.07 . We interpret this as a statistical artifact. This nonsystematic relationship between HHI and CGI can also be seen if we build sub-samples: when 
we split the sample according to whether an observation is above or below the median CGI (HHI) and compare the respective HHI (CGI) we find no significant differences.

\section{Empirical analysis}

We investigate the relationship between corporate governance and firm value across industries with different degrees of product market competition based on a number of alternative empirical setups. Our main approach is similar to the one used by GM. They build terciles of the empirical distribution of all HHIs and assign a dummy variable to each firmyear observation according to whether a firm is in the tercile with the lowest HHI, the medium HHI, or the highest HHI. Based on the results in Petersen (2009), we use pooled fixed effects regressions with standard errors that are clustered at the country level. To control for unobservable heterogeneity that is constant over industry, countries, and years, we use industry, country, and year fixed effects. ${ }^{5} \mathrm{We}$ thus estimate the following regression specification:

$$
Q_{i t}=\alpha_{j}+\alpha_{t}+\alpha_{c}+\boldsymbol{\beta}^{\prime}\left(C G I_{i t} \times \boldsymbol{I}_{i t}\right)+\gamma^{\prime} \boldsymbol{X}_{i t}+\varepsilon_{i t}
$$

where $Q_{i t}$ is Tobin's $\mathrm{Q}$ of firm $i$ in year $t, \alpha_{j}, \alpha_{t}$, and $\alpha_{c}$ are industry-, year-, and country-fixed effects, $C G I_{i t}$ is the governance index, $\boldsymbol{I}_{i t}$ is a $(3 \times 1)$ vector of HHI dummies and $\boldsymbol{X}_{i t}$ is the set of control variables. The elements of $\boldsymbol{X}$ include the logarithm of total assets and the logarithm of firm age. Following GM, we also include the HHI dummies to control for direct effects of competition. Moreover, we interact each control variable with the HHI dummies to control for different effects that the control variables can have in different HHI terciles (for space reasons we do not report the respective coefficients).

We first investigate the average effect of corporate governance on firm value across all industries and hence exclude vector $\boldsymbol{I}_{i t}$ and its interaction with $C G I_{i t}$ as well as its interaction

\footnotetext{
${ }^{5}$ As Coles et al. (2007), GIM, and GM point out, slowly changing explanatory variables, such as our corporate governance index, may render firm fixed effects techniques ineffective. In our setting, firm fixed effects might be especially problematic given that the sample period covers five years only.
} 
with $\boldsymbol{X}_{i t}$ from the regression equation. The results are reported in Column 1 of Table 3. As expected, the coefficient on CGI, our governance index, is positive, indicating an overall positive effect of better governance on firm value. The coefficient, however, is statistically (borderline) insignificant. In Column 2, we allow the effect of governance on firm value to vary in the competitiveness of a company's industry by including interaction terms between the HHI tercile dummy variables and the governance index. The results show that the effect of governance is positive across all three terciles but significant only in the highest tercile of the HHI distribution. Hence, consistent with the hypothesis that competitive pressure enforces discipline on managers to maximize firm value and consequently product market competition acts as a substitute for corporate governance, this result shows that corporate governance significantly increases firm value in non-competitive industries only.

One possible concern with our analysis so far is that our classification of industry competitiveness based on GM is ad-hoc and hence that our results could be driven by the way we have divided industries into terciles. In Columns 3 and 4, we address this concern by considering alternative approaches to differentiate between competitive and non-competitive industries. In Column 3, we construct only two sub-samples of industries based on whether the HHI is above or below the median HHI. Again we find the effect of governance on firm value to be much stronger and (borderline) significant in non-competitive industries as compared to competitive industries where it is insignificant. Even if we further break down the classification scheme and build quartiles instead of terciles from the empirical HHI distribution, the result that governance is significantly related to firm value only in firms operating in noncompetitive industries (whose HHI is in the top quartile of the empirical HHI distribution) holds (Column 4).

In untabulated robustness tests, we have applied further ways to divide our sample into competitive and non-competitive firm-years. For example, if we build HHI quintiles, the posi- 
tive and significant effect of governance is divided among the top two quintiles. Hence, our results do not seem to be sensitive with respect to how we classify competitive and noncompetitive industries. As a further robustness test, we alternatively calculate our HHI-based measure of competition using the firms' total assets instead of sales. The results are reported in Columns 5 to 7 of Table 3. Consistent with the results in Columns 2 to 4, we find the relation between corporate governance and firm value to be stronger (and significant) in noncompetitive industries (with the exception of Column 6 where we use the median-based classification).

In Table 4, we perform a number of further robustness tests. First, we follow Kadyrzhanova and Rhodes-Kropf (2011) and perform regressions of Tobin's Q on our governance index, the HHI, a term interacting the governance index and the HHI, and control variables. For our hypothesis that governance matters more in non-competitive industries to be validated, we would expect a positive coefficient on the interaction term. The results in Column 1 of Table 4 confirm our hypothesis and show a positive and significant coefficient on the interaction term between CGI and the HHI. If we compute the HHI based on the firms' assets, the results remain basically unchanged (Column 2). Further, we perform panel regressions for sub-samples of firm-years in competitive and non-competitive industries. The results for the high-competition sub-sample are reported in Columns 3 and 5 and the results for the low-competition sub-sample in Columns 4 and 6, respectively. In Columns 3 and 4, the HHI is based on sales and in Columns 5 and 6 on total assets. Again, the results confirm our main finding from Table 3. The valuation effect of corporate governance is smaller for firms operating in competitive industries than for firms in non-competitive industries, even though we note that for the HHI based on sales, the valuation effect of corporate governance is significant in both sub-samples (but somewhat larger for non-competitive firms). 
We perform five further robustness checks the results of which we do not report in tables to save space. First, we use the yearly empirical distribution of the HHIs to classify firmyears into competitive and non-competitive industries instead of pooling all firm-year observations. The previous results remain virtually unchanged. Second, we use different data to compute the HHIs. Instead of using the whole universe of listed and unlisted companies, we compute the HHIs only based on listed companies as often done in prior research (e.g., Giroud and Mueller, 2010, 2011). Again, our previous results remain qualitatively and quantitatively unchanged. Third, we construct an alternative version of the governance index and exclude attributes that are in place at more than 90 or less than 10 percent of the sample firms. We thereby attempt to account for the fact that certain governance attributes are adopted by a very large percentage of sample firms and other attributes by almost none (see Table 1). These corporate governance attributes naturally will have a very low variance and potentially weaken the effect of our corporate governance indices. However, all of our results remain qualitatively unchanged when we replace CGI by this alternative governance index. Fourth, we include the percentage of closely held shares as an additional control variable. For European firms, where a controlling shareholder is much more common than in the U.S., the positive effects of governance could be influenced by the existence of a large and controlling shareholder. However, the inclusion of this additional control variable, which is usually positive but insignificant in most specifications, does not qualitatively change any of our results. Moreover, we additionally interact the percentage of closely held shares with our competition measure to check whether the effect is different across different levels of competition. However, the number of closely held shares is consistently insignificant across different levels of product market competition. Fifth, we include a set of country dummies interacted with time dummies in our regressions. We do this to account for the fact that our index, in contrast to GIM's index, has no law component. One concern could thus be that the 14 European countries may differ in how their governance regimes have evolved over time. To filter out the 
effect of governance legislation in these countries, we additionally include country-yearinteraction terms. Our results, however, remain virtually unchanged and, if anything, become somewhat stronger.

The results in this section so far suggest that for companies operating in relatively less competitive markets, agency costs arise from weak corporate governance. We now seek to understand the mechanisms through which corporate governance affects firm value in noncompetitive industries. Prior literature provides some guidance with regards to potential channels, e.g., inefficient investment (GIM), value-destroying acquisitions (Masulis et al., 2007), cost management (Bertrand and Mullainathan, 2003), or cash management (Dittmar and Mahrt-Smith, 2007). To address these questions, we use the same empirical specification as in Equation 1 but use a different dependent variable, depending on which mechanism we test. ${ }^{6}$ The results presented in Table 5 show that we are able to identify three channels through which Tobin's Q may be affected by corporate governance in relatively less competitive industries.

In Columns 1 and 2 of Table 5, the dependent variable is capital expenditures divided by total assets. In Column 1, the positive coefficient on CGI indicates that across all levels of product market competition, corporate governance has a positive effect on capital expenditures. While this might be surprising according to the inefficient investment arguments put forward by GIM, recent evidence using international (e.g., Aggarwal et al., 2009) or U.S. samples (e.g., Bebchuk and Cohen, 2005; Hoechle et al., 2010) shows that capital expenditures have, in fact, a positive effect on firm value when capital expenditures are included in standard firm-value regressions. When differentiating between different levels of competition, the results in Column 2 of Table 5 reveal that the positive effect of governance on capital expenditures can only be observed in the top two terciles of product market competition and

\footnotetext{
${ }^{6}$ All of our results continue to hold if we use the alternative specifications we have used for the firm-value analysis in Table 4, e.g., the interaction term between competition and governance or the sub-sample analysis.
} 
hence for companies that are operating in relatively less competitive industries whereas there is no effect for companies operating in the most competitive industries. In Columns 3 and 4 of Table 5, the dependent variable is the sum of the value of all acquisitions made by a firm in a given year divided by the firm's total assets in that given year. In Column 3, the negative coefficient on the CGI is further evidence of the well-known result that the negative returns to acquirer stocks after they announce a bid for another firm are correlated with agency problems such as low managerial ownership (Lewellen et al., 1985) or high free cash flow (Lang et al., 1991). Additionally, long-run evidence indicates negative abnormal performance by firms who acquire other firms (see, e.g., Loughran and Vijh, 1997; Rau and Vermaelen, 1998). In Column 4, however, we see that the effect of governance on acquisition spending is concentrated on firms in non-competitive industries only. Finally, in Columns 5 and 6 of Table 5, the dependent variable is a dummy variable that is equal to 1 if a company is diversified and 0 if not. We define a company as being diversified if, in a given year, the company has sales in two product market segments with different SIC codes. As can be seen in Column 5, governance has a slightly positive (but non-significant) effect on diversification. When we distinguish between firms operating in competitive and firms operating in non-competitive industries in Column 6, it becomes evident that governance has a negative effect on (valuedestroying) diversification in non-competitive industries, indicating that for firms operating in these industries, having better governance leads them to diversify less, which will also contribute to the firm-value results we found above. ${ }^{7}$ We have to caution though that none of the individual coefficients on the interaction terms between governance and competition are significant in the diversification-regressions. Summarizing our results, we find that a combination of three mechanisms (increased capital expenditures, less spending on acquisitions, and smaller likelihood to diversify) is the likely driver of our earlier results.

\footnotetext{
${ }^{7}$ Our analyses for the other mechanisms we tested, namely labor productivity, cost efficiency, real wages, selling, general, and administrative expenses, research and development expenses, cash holdings, and payout yielded no systematic patterns across HHI terciles. Therefore, these results are not reported in a table.
} 
Unreported robustness tests confirm our results above. Whether we winsorize the capital expenditures or the acquisitions variable, whether we define being diversified on the 2digit SIC-code, or whether we use a dummy variable that is equal to 1 if a company has an acquisition in a given year to define whether a company has done acquisitions and estimate the regressions with probit regressions all have no influence on our results.

\section{Conclusions}

In this paper, we present new evidence on the influence of product market competition on the valuation effect of corporate governance. Recent U.S. evidence shows that firms in less competitive industries benefit more from good corporate governance than firms in more competitive industries and, hence, a competitive product market acts as a substitute for an efficient corporate governance structure (e.g., Giroud and Mueller, 2010, 2011; Kadyrzhanova and Rhodes-Kropf, 2011). However, all of these studies focusing on U.S. firms are plagued by similar problems in the measurement of corporate governance and competition. First, they measure corporate governance by GIM's index which strongly focuses on anti-takeover provisions. Second, to measure product market competition, all those studies either use a HHI based on listed companies (included in the Compustat universe) only, a HHI from the U.S. Economic Census, which is calculated using the largest 50 companies within each industry, or a concentration measure from the U.S. Economic Census, which is based on the largest four companies within each industry.

In this study, we provide external validity of prior U.S. findings by investigating the relation between product market competition, corporate governance, and firm value in a large international sample covering 14 EU countries. We use more comprehensive and reliable

measures of product market competition and corporate governance than used in previous U.S.-based research. We measure competition based on a HHI over all listed firms contained 
in Thomson Financial's Worldscope database and all non-listed firms contained in Bureau van Dijk's Amadeus database which provides extensive coverage of non-listed firms throughout Europe. To construct our corporate governance index, we use a large set of 64 individual corporate governance variables related to board accountability, financial disclosure and internal control, shareholder rights, remuneration, market for control, and corporate behavior.

Our results suggest that corporate governance is significantly positively related to firm value in non-competitive industries only. Hence, our findings are consistent with the hypothesis that product market competition acts as a substitute for corporate governance as competitive pressure enforces discipline on managers to maximize firm value. We find that a combination of increased capital expenditures, less resources spent on acquisitions, and a smaller likelihood to engage in diversification are the likely mechanisms through which corporate governance may positively affect firm value in non-competitive industries. All results are robust to a large number of robustness checks including alternative ways to classify observations into competitive and non-competitive firm-years, an alternative corporate governance index, and estimating alternative regressions specifications.

One question that might arise from the results we have presented in our paper is why firms in non-competitive industries ever choose low levels of corporate governance. One possible answer could be that for a manager who wants to pursue his own interests, such as for example managerial empire building, a relatively weak corporate governance and low degree of product market competition is the most preferable setup. Hence, there is a lower valuation associated with these companies as shareholders take the higher agency costs resulting from such a firm-structure into account. We provide some evidence pointing to this direction in Table 5 where we show that poorly-governed firms in non-competitive industries are more likely to pursue diversification strategies and to make acquisitions. For managers it might thus very well be beneficial to have a poor corporate governance also in a non-competitive envi- 
ronment and, in turn, their ability to maintain a poor firm-level corporate governance is again related to the corporate governance that is in place already. Hence, poorly governed firms might remain poorly governed firms in a non-competitive environment at least as long as the expropriation of private benefits exceeds the benefits accruing to managers from increases in the company's market value or external control mechanisms exert pressure towards a stronger corporate governance. 


\section{References}

Adams, R.B., Almeida, H., and D. Ferreira, 2005, Powerful CEOs and their impact on corporate performance, Review of Financial Studies 18, 1403-1432.

Aggarwal, R., Erel, I., Stulz, R., and R. Williamson, 2009, Differences in governance practice between U.S. and foreign firms: measurement, causes, and consequences, Review of Financial Studies 22, 3131-3169.

Agrawal, A., and C.R. Knoeber, 1996, Firm performance and mechanisms to control agency problems between managers and shareholders, Journal of Financial and Quantitative Analysis 31, 377-397.

Ali, A., Klasa, S., and E. Yeung, 2009, The limitations of industry concentration measures constructed with Compustat data: implications for finance research, Review of Financial Studies 22, 3839-3871.

Baggs, J., and J.-E. De Bettignies, 2007, Product market competition and agency costs, Journal of Industrial Economics 55, 289-323.

Bebchuk, L., and A. Cohen, 2005, The costs of entrenched boards, Journal of Financial Economics 78, 409-433.

Bebchuk, L., Cohen, A., and A. Ferrell, 2009, What matters in corporate governance?, Review of Financial Studies 22, 783-827.

Beiner, S., Schmid, M.M., and G. Wanzenried, 2011, Product market competition, managerial incentives and firm valuation, European Financial Management, forthcoming.

Bertrand, M., and S. Mullainathan, 2003, Enjoying the quiet life? Corporate governance and managerial preferences, Journal of Political Economy 111, 1043-1075.

Chhaochharia, V. and Y. Grinstein, 2007, Corporate governance and firm value: The impact of the 2002 governance rules, Journal of Finance 62, 1789-1825.

Chhaochharia, V., Grullon, G., Grinstein, Y., and R. Michaely, 2009, Product market competition and agency conflicts: Evidence from the Sarbanes Oxley law, Working Paper, Cornell University. 
Coles, J., Lemmon, M. and F. Meschke, 2007, Structural models and endogeneity in corporate finance: The link between managerial ownership and corporate performance, Working Paper, Arizona State University.

Core, J., Guay, W.R. and T. O. Rusticus, 2006, Does weak governance cause weak stock returns? An examination of firm operating performance and investors' expectations, Journal of Finance 61, 655-687.

Cremers, M., and V. B. Nair, 2005, Governance mechanisms and equity prices, Journal of Finance 60, 2859-2894.

Cremers, M., Nair, V. B., and U. Peyer, 2008, Takeover defenses and competition: The role of stakeholders, Journal of Empirical Legal Studies 5, 791-818.

Cuñat, V., and M. Guadalupe, 2005, How does product market competition shape incentive contracts?, Journal of the European Economic Association 3, 1058-82.

Dittmar, A. and J. Mahrt-Smith, 2007, Corporate Governance and the Value of Cash Holdings, Journal of Financial Economics 83, 599-634.

Drobetz, W., Schillhofer, A. and H. Zimmermann, 2004, Corporate governance and expected stock returns: evidence from Germany, European Financial Management 10, 267-93.

Faleye, O., 2007, Classified boards, firm value, and managerial entrenchment, Journal of Financial Economics 83, 501-529.

Giroud, X., and H. Mueller, 2010, Does corporate governance matter in competitive industries?, Journal of Financial Economics 95, 312-331.

Giroud, X., and H. Mueller, 2011, Corporate governance, product market competition, and equity prices, Journal of Finance, forthcoming.

Gompers, P., Ishii, J., and A. Metrick, 2003, Corporate governance and equity prices, The Quarterly Journal of Economics 118, 107-155.

Habib, M.A., and A. Ljungqvist, 2005, Firm value and managerial incentives: A stochastic frontier approach, Journal of Business 78, 2053-2093.

Hoechle, D., Schmid, M.M., Walter, I., and D. Yermack, 2010, How much of the diversification discount can be explained by poor corporate governance? Working Paper, New York University. 
Kadyrzhanova, D., and M. Rhodes-Kropf, 2011, Concentrating on governance, Journal of Finance, forthcoming.

Lang, L. H. P., Stulz, R., and R. A. Walkling, 1991, A Test of the Free Cash Flow Hypothesis: The Case of Bidder Returns, Journal of Financial Economics 29, 315-335.

Lewellen, W., Loderer, C., and A. Rosenfeld, 1985, Merger Decisions and Executive Stock Ownership in Acquiring Firms, Journal of Accounting and Economics 7, 209-231.

Loderer, C., and U. Peyer, 2002, Board overlap, seat accumulation and share prices, European Financial Management 8, 165-92.

Loughran, T., and A. M. Vijh, 1997, Do Long-Term Shareholders Benefit from Corporate Acquisitions ?, Journal of Finance 52, 1765-1790.

Masulis, R. W., Wang, C., and F. Xie, 2007, Corporate governance and acquirer returns, Journal of Finance 62, 1851-1889.

Petersen, M., 2009, Estimating Standard Errors in Finance Panel Data Sets: Comparing Approaches, Review of Financial Studies 22, 435-480.

Rau, P.R., and T. Vermaelen, 1998, Glamour, Value and the Post-Acquisition Performance of Acquiring Firms, Journal of Financial Economics 49, 223-253.

Yermack, D., 1996, Higher market valuation for firms with a small board of directors, Journal of Financial Economics 40, 185-211. 
Table 1: List of Corporate Governance Attributes and the Percentage of Firms Meeting the Requirements for these Attributes

\begin{tabular}{|c|c|}
\hline Individual governance attribute & $\begin{array}{c}\% \text { of firms meeting } \\
\text { attributes }\end{array}$ \\
\hline \multicolumn{2}{|l|}{ Board Accountability } \\
\hline 1. Board members are subject to annual election by all shareholders & $8.0 \%$ \\
\hline 2. Non-executive board members have a formal session without executives once a year & $68.9 \%$ \\
\hline 3. Board performance is periodically evaluated & $83.5 \%$ \\
\hline 4. Company discloses a code of ethics for senior executives & $40.5 \%$ \\
\hline 5. Company discloses its corporate governance policies or guidelines & $80.1 \%$ \\
\hline 6. Board or a committee is responsible for CEO succession planning & $87.7 \%$ \\
\hline 7. Company has not failed to adopt the recommendations of a shareholder proposal & $99.8 \%$ \\
\hline 8. All executive board members own shares after excluding options held & $69.4 \%$ \\
\hline 9. All non-executive board members own shares after excluding options held & $44.5 \%$ \\
\hline 10. Company has a separated chairman and CEO & $89.2 \%$ \\
\hline 11. All members attended at least $75 \%$ of the board meetings & $83.2 \%$ \\
\hline 12. Company has a designated "lead" or senior non-executive board member & $43.7 \%$ \\
\hline 13. There have been no related-party transactions in the past three years & $51.6 \%$ \\
\hline 14. The governance/nomination committee is composed of independent board members & $23.2 \%$ \\
\hline 15. No former CEO of the company serves on the board & $74.5 \%$ \\
\hline 16. Nr. of shares held by officers and directors has not decreased by $10 \%$ or more & $86.0 \%$ \\
\hline 17. Nr. of shares held by officers and directors has increased by $10 \%$ or more & $29.0 \%$ \\
\hline 18. Governance/nomination committee has a written charter or terms of reference & $66.8 \%$ \\
\hline 19. Board size is greater than five but less than 16 & $79.8 \%$ \\
\hline 20. Board is controlled by more than $50 \%$ of independent outside directors & $48.7 \%$ \\
\hline \multicolumn{2}{|l|}{ Financial Disclosure and Internal Control } \\
\hline 21. Company has not had a material earnings restatement in the past three years & $98.6 \%$ \\
\hline 22. Audit committee has a written charter or terms of reference & $84.8 \%$ \\
\hline 23. Company has not received a qualified audit opinion within the last two fiscal years & $99.1 \%$ \\
\hline 24. Company is not currently under investigation for accounting irregularities & $98.7 \%$ \\
\hline 25. Audit committee is wholly composed of independent board members & $55.0 \%$ \\
\hline 26. Someone other than senior management with sole authority to hire outside auditor & $74.6 \%$ \\
\hline 27. Audit committee with sole authority to approve non-audit services from outside auditor & $49.3 \%$ \\
\hline 28. Company did not pay its auditor less for audit related services than for other services & $77.9 \%$ \\
\hline \multicolumn{2}{|l|}{ Shareholder Rights } \\
\hline 29. Vote results for the last shareholder meeting are disclosed within 14 calendar days & $70.1 \%$ \\
\hline 30. All common or ordinary equity shares have one-share, one-vote, with no restrictions & $85.0 \%$ \\
\hline 31. The company provides confidential voting with no or with reasonable exceptions & $76.4 \%$ \\
\hline 32. Shareholders have a right to convene an EGM with $10 \%$ or less of the shares requesting one & $85.0 \%$ \\
\hline 33. Shareowners have a right to act in concert through written communication & $22.7 \%$ \\
\hline 34. Voting rights are not capped at a certain percentage & $94.7 \%$ \\
\hline \multicolumn{2}{|l|}{ Remuneration } \\
\hline 35. Non-executive board members paid in cash and some form of stock-linked compensation & $7.4 \%$ \\
\hline 36. Company discloses performance targets for the next fiscal year & $50.7 \%$ \\
\hline 37. Non-executive board members are paid entirely in some form of stock-linked compensation & $0.2 \%$ \\
\hline 38. CEO without an employment agreement that provides for guaranteed bonus payments & $96.0 \%$ \\
\hline 39. Goals used to determine incentive awards are aligned with the company's financial goals & $73.2 \%$ \\
\hline 40. CEO/Managing Director does not sit on the remuneration committee & $96.6 \%$ \\
\hline 41. Remuneration committee is wholly composed of independent board members & $48.6 \%$ \\
\hline 42. No repricing of outstanding executive stock options and no option exchange program & $97.5 \%$ \\
\hline 43. Expensing of employee stock option grants & $39.0 \%$ \\
\hline 44. Remuneration committee has a written charter or terms of reference & $74.6 \%$ \\
\hline 45. Potential Dilution from Stock Options Outstanding is below $20 \%$ & $77.4 \%$ \\
\hline
\end{tabular}




\section{Market for Control}

47. Company has not adopted a shareholder rights plan ("poison pill") 98.7\%

48. Company does not have a staggered ("classified") board $39.4 \%$

49. Company cannot issue blank check preferred stock in the event of a hostile tender offer $82.1 \%$

50. Company's shareholder rights plan ("poison pill") has been ratified by a shareholder vote $0.8 \%$

51. Fair price provision in place or price protection under applicable law $82.4 \%$

52. Shareholder rights plan includes a TIDE provision or a three-year sunset provision $0.1 \%$

53. Company does not require a supermajority vote to approve a merger $63.1 \%$

54. No single shareholder or shareholder group whit majority of voting power $82.4 \%$

55. Company allows cumulative voting in the election of directors $2.7 \%$

\section{Corporate Behavior}

56. The company have a policy addressing workplace safety

57. Company does not have pending criminal litigation against it

58. No allegation that the company used sweat shops within the last three years $99.7 \%$

59. Company discloses its environmental performance $54.2 \%$

60. Company discloses its workplace safety record $37.6 \%$

61. No regulatory investigation for a material issue other than for accounting irregularities $90.6 \%$

62. Company discloses its policy regarding corporate level political donations $30.2 \%$

63. Company has not been charged with workplace safety violations within the last two years $98.5 \%$

64. It has not been alleged by a responsible party that the company used child labor $99.9 \%$

This table reports the 64 governance attributes included in our sample grouped by GMI's six sub-categories: Board Accountability, Financial Disclosure and Internal Control, Shareholder Rights, Remuneration, Market for Control, and Corporate Behavior. For each governance attribute, we report the percentage of firms in the sample that meet the respective criteria associated with this attribute. The sample consists of 3,102 firm-years. 
Table 2: Descriptive Statistics of Main Variables

\begin{tabular}{lcccccc}
\hline & Mean & Median & Max & Min & Std.Dev & Obs. \\
\hline $\mathrm{Q}$ & 1.73 & 1.39 & 13.68 & 0.56 & 1.12 & 3,102 \\
$\mathrm{CGI}$ & 64.09 & 64.71 & 88.89 & 25.00 & 10.84 & 3,102 \\
$\mathrm{HHI}$ & 0.024 & 0.014 & 0.401 & 0.002 & 0.03 & 3,102 \\
\hline
\end{tabular}

This table reports descriptive statistics for the main variables used in the paper. Q denotes Tobin's Q and is computed as the sum of total assets less the book value of equity plus the market value of equity, divided by total assets, CGI denotes the governance index which is constructed by dividing the governance attributes a company fulfills by the number of total governance attributes. HHI denotes the Herfindahl-Hirschman-Index which is constructed by summing up the squared market shares of all firms in a given industry and dividing it by the square of the sum of all market shares using listed and unlisted firms of all countries. 
Table 3: Corporate Governance, Competition, and Firm Value

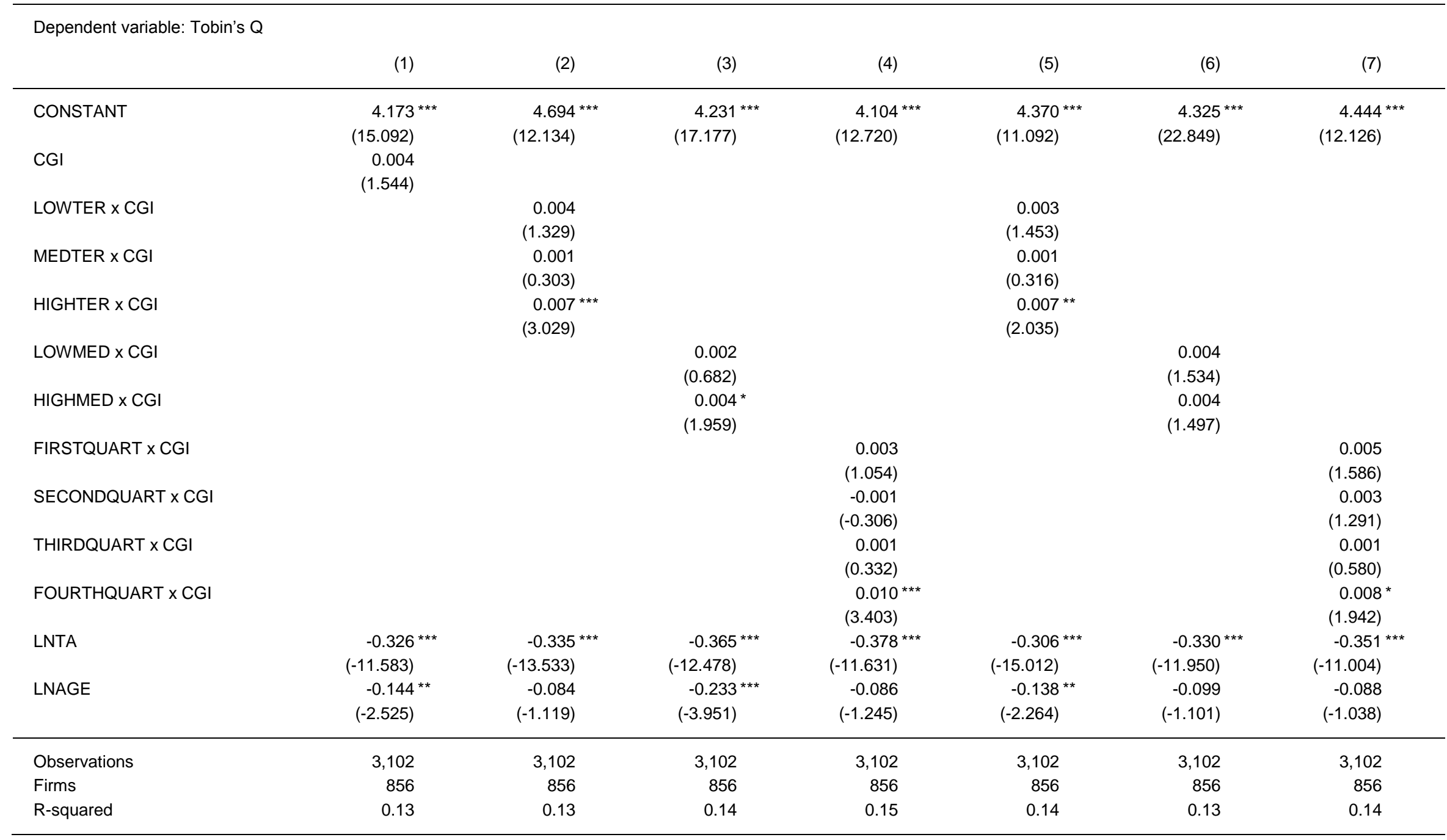


This table reports the results from panel regressions of Tobin's Q on HHI dummies, the governance index, two control variables, and interaction terms between the HHI dummies and the governance index and between the HHI dummies and the control variables. All regressions include year-, industry-, and country-fixed effects. The governance index is built additively from the 64 governance attributes described in Table 1. The HHI dummies indicate whether the HHI is in the highest, middle, or lowest tercile of its empirical distribution (Column 2 and 5), whether the HHI is above or below the median HHI (Columns 3 and 6), or whether the HHI is in the first, second, third, or fourth quartile (Columns 4 and 7). In Columns 2 to 4 , the HHIs are based on the distribution of company sales and in Columns 5 to 7, the HHIs are based on the distribution of company total assets within the respective industry. In Columns 2 to

7 , the intercept, the governance index, and the control variables are interacted with the HHI dummies. For space reasons only the interaction terms between the governance index and the HHI dummies are reported. All industries are defined by 2-digit-SIC codes. The control variables are firm size, proxied by the logarithm of total assets (LNTA), and the log of a firm's age, proxied by the time since the beginning of trading (LNAGE). The sample period is from 2003 to 2007 . $t$-statistics are in parentheses and allow for clustering at the country level. $*, * *$, and $* * *$ denotes statistical significance at the $10 \%, 5 \%$, and $1 \%$ level, respectively. 
Table 4: Corporate Governance, Competition, and Firm Value - Alternative Specifications and Sub-Sample Analysis

\begin{tabular}{|c|c|c|c|c|c|c|}
\hline \multicolumn{7}{|c|}{ Dependent variable: Tobin's Q } \\
\hline & \multicolumn{2}{|l|}{ Full sample } & \multirow{2}{*}{$\begin{array}{l}\text { High competition } \\
\text { (3) }\end{array}$} & \multirow{2}{*}{$\begin{array}{r}\text { Low competition } \\
(4)\end{array}$} & \multirow{2}{*}{$\begin{array}{r}\text { High competition } \\
\text { (5) }\end{array}$} & \multirow{2}{*}{$\begin{array}{r}\text { Low competition } \\
(6)\end{array}$} \\
\hline & (1) & (2) & & & & \\
\hline \multirow[t]{2}{*}{ CONSTANT } & $4.079^{* * *}$ & $4.538^{* * *}$ & $4.138^{* * *}$ & $5.732^{* * *}$ & $4.501^{* * *}$ & $4.067^{* * *}$ \\
\hline & $(16.680)$ & $(16.423)$ & $(9.898)$ & $(16.186)$ & $(13.331)$ & $(13.431)$ \\
\hline \multirow[t]{2}{*}{ CGI } & 0.002 & 0.002 & $0.003^{*}$ & $0.004^{*}$ & 0.004 & $0.005^{* *}$ \\
\hline & $(1.118)$ & $(0.925)$ & $(1.653)$ & $(1.865)$ & $(0.938)$ & $(2.491)$ \\
\hline \multirow[t]{2}{*}{$\mathrm{CGI} \times \mathrm{HHI}$} & 0.058 ** & $0.053^{* \star *}$ & & & & \\
\hline & $(2.078)$ & $(4.132)$ & & & & \\
\hline \multirow[t]{2}{*}{$\mathrm{HHI}$} & $-4.416^{* *}$ & $-2.980^{* * *}$ & & & & \\
\hline & $(-2.393)$ & $(-3.255)$ & & & & \\
\hline \multirow[t]{2}{*}{ LNTA } & $-0.324^{\star \star \star}$ & $-0.323^{* * *}$ & $-0.301^{\star * *}$ & $-0.421^{\star \star *}$ & $-0.363^{* \star \star}$ & $-0.324^{* \star *}$ \\
\hline & $(-11.539)$ & $(-11.431)$ & $(-3.920)$ & $(-9.241)$ & $(-6.198)$ & $(-11.258)$ \\
\hline \multirow[t]{2}{*}{ LNAGE } & $-0.014^{* *}$ & $-0.014^{* *}$ & -0.005 & $-0.017^{* * *}$ & -0.001 & $-0.019^{* * *}$ \\
\hline & $(-2.537)$ & $(-2.504)$ & $(-0.973)$ & $(-3.166)$ & $(-0.169)$ & $(-3.832)$ \\
\hline Observations & 3,102 & 3,102 & 1,535 & 1,567 & 1,526 & 1,576 \\
\hline Firms & 856 & 856 & 502 & 535 & 465 & 516 \\
\hline R-squared & 0.13 & 0.14 & 0.17 & 0.14 & 0.17 & 0.14 \\
\hline
\end{tabular}

This table reports the results from panel regressions of Tobin's $\mathrm{Q}$ on the governance index, two control variables, and year-, industry-, and country-fixed effects. Columns 1 and 2 additionally include the HHI and an interaction term between the governance index and HHI. The governance index is built additively from the 64 governance attributes described in Table 1 . In Columns 1 , 5 , and 6, the HHIs are based on the distribution of company sales, in Columns 2,3 , and 4, the HHIs are based on the distribution of company total assets within the respective industry. In Columns 3 to 6, the sample is split into sub-samples according to whether a company's HHI is below (= high competition) or above (= low competition) the median HHI. All industries are defined by 2-digit-SIC codes. The control variables are firm size, proxied by the logarithm of total assets (LNTA), and the log of a firm's age, proxied by the time since the beginning of trading (LNAGE). The sample period is from 2003 to 2007 . $t$-statistics are in parentheses and allow for clustering at the country level. ***, and $* * *$ denotes statistical significance at the $10 \%, 5 \%$, and $1 \%$ level, respectively. 
Table 5: Capital Expenditures, Acquisitions, and Diversification

\begin{tabular}{|c|c|c|c|c|c|c|c|c|c|c|c|c|}
\hline \multirow[t]{2}{*}{ Dependent Variable: } & \multicolumn{4}{|c|}{ Capital Expenditures } & \multicolumn{4}{|c|}{ Acquisitions } & \multicolumn{4}{|c|}{ Diversification } \\
\hline & (1) & & (2) & & (3) & & (4) & & (5) & & (6) & \\
\hline CONSTANT & $\begin{array}{r}11.109 \\
(13.873)\end{array}$ & $* * *$ & $\begin{array}{l}13.202 \\
(8.042)\end{array}$ & $* * *$ & $\begin{array}{r}2.813 \\
(1.830)\end{array}$ & * & $\begin{array}{r}6.064 \\
(3.125)\end{array}$ & $* * *$ & $\begin{array}{r}-0.814 \\
(-2.443)\end{array}$ & $* *$ & $\begin{array}{r}-0.922 \\
(-2.047)\end{array}$ & ** \\
\hline CGI & $\begin{array}{r}0.026 \\
(1.732)\end{array}$ & * & & & $\begin{array}{r}-0.280 \\
(-2.734)\end{array}$ & $\star \star *$ & & & $\begin{array}{r}0.003 \\
(0.795)\end{array}$ & & & \\
\hline LOWTER $\times$ CGI & & & $\begin{array}{r}0.006 \\
(0.247)\end{array}$ & & & & $\begin{array}{r}-0.031 \\
(-1.596)\end{array}$ & & & & $\begin{array}{r}0.007 \\
(1.389)\end{array}$ & \\
\hline MEDTER $\times$ CGI & & & $\begin{array}{r}0.031 \\
(2.171)\end{array}$ & ** & & & $\begin{array}{r}-0.014 \\
(-1.300)\end{array}$ & & & & $\begin{array}{r}0.008 \\
(1.487)\end{array}$ & \\
\hline HIGHTER $\times$ CGI & & & $\begin{array}{r}0.039 \\
(2.049)\end{array}$ & ** & & & $\begin{array}{r}-0.041 \\
(-2.530)\end{array}$ & $* *$ & & & $\begin{array}{r}-0.008 \\
(-1.340)\end{array}$ & \\
\hline LNTA & $\begin{array}{r}-0.457 \\
(-5.612)\end{array}$ & $* \star \star$ & $\begin{array}{r}-0.289 \\
(-3.469)\end{array}$ & $* * *$ & $\begin{array}{r}0.139 \\
(3.059)\end{array}$ & $* * *$ & $\begin{array}{r}-0.133 \\
(-1.515)\end{array}$ & & $\begin{array}{r}0.149 \\
(7.937)\end{array}$ & $* * *$ & $\begin{array}{r}0.153 \\
(4.386)\end{array}$ & *** \\
\hline LNAGE & $\begin{array}{r}-0.188 \\
(-1.237)\end{array}$ & & $\begin{array}{r}-0.044 \\
(-0.092)\end{array}$ & & $\begin{array}{r}-0.499 \\
(-2.646)\end{array}$ & $* * *$ & $\begin{array}{r}-0.287 \\
(-0.845)\end{array}$ & & $\begin{array}{r}0.229 \\
(6.070)\end{array}$ & $* * *$ & $\begin{array}{r}0.107 \\
(1.660)\end{array}$ & * \\
\hline Observations & 3,057 & & 3,057 & & 2,698 & & 2,698 & & 2,871 & & 2,871 & \\
\hline Firms & 852 & & 852 & & 794 & & 794 & & 810 & & 810 & \\
\hline R-squared & 0.18 & & 0.19 & & 0.08 & & 0.08 & & 0.13 & & 0.13 & \\
\hline
\end{tabular}

This table reports the coefficients from panel regressions of either capital expenditures, acquisitions, or a dummy whether a company is diversified on year, country, and industry fixed effects, CGI, and control variables. The control variables are the same as in Table 3 . In columns 2,4 , and 6 , CGI is interacted with HHI dummies, and HHI dummies are included as additional control variables (not reported). In columns 1 and 2, the dependent variable is capital expenditures divided by total assets. In columns 3 and 4 , the dependent variable is the sum of the value of all acquisitions made by a firm in a given year divided by the firm's total assets in that year. In columns 5 and 6 the dependent variable is a dummy variable which equals one if a company is diversified in a given year and zero if it is not. Columns 5 and 6 are based on probit regressions. In columns 5 and 6, the R-squared is McFadden's pseudo R-squared. Columns 1, 3, and 5 report the coefficients on CGI, and columns 2, 4, and 6 report the coefficients on interaction terms between CGI and HHI dummies. All coefficients in Columns 1 to 4 are multiplied by 100. The sample period is from 2003 to 2007. t-statistics are in parentheses and allow for clustering at the country level. *,**, and *** denotes significance at the $10 \%, 5 \%$, and $1 \%$ level, respectively. 